\title{
Pengaruh Efektivitas Sistem Informasi Akuntansi, Kesesuaian Tugas, Kenyamanan Fisik dan Lingkungan Kerja pada Kinerja Karyawan
}

\author{
L.G. Sridarmaningrum ${ }^{1}$ \\ Ni Luh Sari Widhiyani \\ ${ }^{1}$ Fakultas Ekonomi dan Bisnis Universitas Udayana (Unud), Bali, Indonesia \\ email: harum.sridarmaningrum@yahoo.com/ Telp: +6285738233626 \\ ${ }^{2}$ Fakultas Ekonomi dan Bisnis Universitas Udayana (Unud), Bali, Indonesia
}

\begin{abstract}
ABSTRAK
Kinerja karyawan mempengaruhi keberhasilan sebuah perusahaan, termasuk lembaga keuangan baik lembaga keuangan bank maupun non bank seperti Lembaga Perkreditan Desa (LPD). Penelitian dilakukan untuk mengetahui pengaruh efektivitas penerapan sistem informasi akuntansi (SIA), kesesuaian tugas, kenyamanan fisik dan lingkungan kerja pada kinerja karyawan LPD di Kota Denpasar. Penelitian dilaksanakan di 35 LPD yang terdapat di Kota Denpasar. Populasi yang digunakan ialah karyawan yang menggunakan sistem terkomputerisasi sejumlah 212 orang pada LPD di Kota Denpasar. Metode pengambilan sampel yang digunakan adalah metode nonprobability samplingdengan teknik purposive sampling berdasarkan pertimbangan tertentu. Total sampel yang diambil sebanyak 105 orang yang berhubungan dengan SIA. Pengumpulan data dilakukan dengan menyebarkan kuesioner, wawancara dan observasi kepada LPD di Kota Denpasar. Teknik analisis menggunakan analisis regresi linier berganda.Penelitian ini memberikan hasil bahwa variabel efektivitas penerapan SIA, kesesuaian tugas, kenyamanan fisik dan lingkungan kerja berpengaruh positif pada kinerja karyawan.

Kata kunci: efektivitas penerapan SIA, kesesuaian tugas, kenyamanan fisik, lingkungan kerja, kinerja karyawan.
\end{abstract}

\begin{abstract}
Employee performance affects the success of a company, including financial institutions both bank and non-bank financial institutions such as Lembaga Perkreditan Desa (LPD). The purpose of this study is to determine the effect of effectiveness of the application of accounting information system (SIA), suitability of tasks, physical comfort and work environment on the performance of LPD employees in Denpasar City. The population in this study are employees who use computerized system of 212 people in LPD in Denpasar City. Sampling method used is nonprobability sampling method. Total samples taken as many as 105 people associated with SIA. The data was collected by distributing questionnaires, interviews and observations to LPDs in Denpasar City. The analysis technique used multiple linear regression analysis. The results of this study indicate that the effectiveness of the implementation of SIA, suitability, physical comfort and work environment have a positive effect on employee performance.

Keywords: effectiveness of accounting information system implementation, task conformity, physical comfort, work environment, employee performance
\end{abstract}

\section{PENDAHULUAN}

Desa pakraman memiliki beberapa hak otonomi, salah satu hak otonomi tersebut adalah mengatur hubungan antara anggota kelompok masyarakat dan melakukan 
L. G. Sridarmaningrum dan Ni Luh Sari Widhiyani. Pengaruh ...

pengelolaan terhadap kekayaan yang dimiliki oleh desa pekraman. Desa pakraman dituntut untuk memiliki tata kelola perekonomian sendiri salah satunya adalah Lembaga Perkreditan Desa (LPD). LPD harus memiliki pengelolaan keuangan yang baik. Pengelolaan keuangan tersebut tentu tidak terlepas dari adanya teknologi informasi yang terdapat pada masing-masing LPD.

Teknologi informasi sangatlah dibutuhkan terutama dalam bidang akuntansi. Kelton et al (2010) menyatakan perkembangan teknologi yang pesat memberi dampak positif bagi perusahaan. Kemampuan bersaing perusahaan menentukan bagaimana kelangsungan hidup perusahaan nantinya. Informasi akuntansi yang berkualitas menjadi salah satu hal penting bagi perusahaan sebab informasi tersebut menjadi dasar dalam pengambilan keputusan (Nwokeji, 2012). Sistem informasi akuntansi menjadi salah satu sarana penting bagi perusahaan dalam meningkatkan kinerjanya (Al-eqab dan Adel, 2013). Fungsi utama dari sistem informasi akuntansi yaitu memroses data-data transaksi keuangan menjadi informasi-informasi yang dapat digunakan oleh para pemangku kepentingan (Marija et al, 2011).

Sistem informasi akuntansi adalah sistem yang terkait dengan teknologi di bidang akuntansi yang dapat membantu dalam pengelolaan dan pengendalian data-data serta informasi-informasi keuangan (Urquia et al, 2011). Hal ini mendorong pemrosesan data-data akuntansi yang semula menggunakan cara manual menjadi pemrosesan data akuntansi secara terkomputerisasi. Bodnar dan Hopwood (2006) menyatakan bahwa informasi adalah data yang diolah sehingga 
dapat dijadikan dasar untuk mengambil keputusan yang tepat. Adanya perkembangan teknologi informasi dan komunikasi yang semakin maju menjadikan sistem informasi akuntansi sebagai suatu alat yang penting dalam dunia bisnis yang semakin kompetitif (Ogah et al., 2013).

Sistem informasi akuntansi membantu para pebisnis dalam mencapai efisiensi dan efektivitas dalam pengambilan keputusan (Edison et al., 2012). Akuntansi merupakan bagian dari sistem yang menduduki posisi penting di dalam proses administrasi pemerintah maupun instansi lembaga keuangan lainnya. Sistem informasiadalah konsep yang menjadi dasar dalam evaluasi terhadap sistem serta kualitas suatu informasi (Rai et al., 2002). SIA merupakan bagian penting dari suatu sistem informasi yang menerima dan memroses data-data keuangan menjadi informasi yang disajikan untuk para pemangku kepentingan baik di dalam maupun di luar organisasi.

Kinerja karyawan harus diketahui oleh para pihak yang berkepentingan agar dapat dilihat bagaimana perkembangan karyawan dalam pencapaian tujuan organisasi (George et al., 2012). Upaya meningkatkan kinerja karyawan dalam penggunaan sistem informasi akuntansi dapat dipengaruhi oleh faktor efektivitas penerapan SIA, kesesuaian tugas, kenyamanan fisik serta lingkungan kerja. Faktor-fakor tersebut sangatlah berpengaruh terhadap kinerja karyawan dalam melaksanakan sistem pengolahan datanya. Efektivitas sistem informasi akuntansi mampu memberikan kemudahan terhadap penggunanya serta kepuasan dalam menyelesaikan tugas. Kesesuian tugas dalam mengerjakan tugas merupakan faktor 
L. G. Sridarmaningrum dan Ni Luh Sari Widhiyani. Pengaruh ...

penentu apakah sistem yang digunakan oleh karyawan sesuai dengan tugas yang dikerjakannya.

Kenyamanan fisik merupakan faktor dimana kinerja karyawan dalam mengerjakan tugas ditentukan oleh teknologi yang terkomputerisasi tersebut, apabila komputer yang digunakan dalam memroses data tersebut bermasalah maka kinerja penggunapun akan terhambat. Faktor lingkungan kerja juga merupakan salah satu penentu apakah kinerja karyawan dapat berjalan dengan baik atau tidak, karena apabila lingkungan kerja di tempat karyawan bekerja tersebut sangatlah buruk seperti hubungan antara karyawan dan atasan tidak baik serta suasana kerja yang tidak mendukung dapat mengakibatkan kinerja karyawan dalam menggunakan sistem informasi informasi akuntansi tersebut tidak berjalan dengan baik sehingga tugas-tugas yang dikerjakan akan terganggu atau terhambat, oleh sebab itu faktor-faktor diatas sangatlah menentukan tingkat keberhasilan kinerja karyawan dalam menjalankan fungsi serta tugasnya.

Sistem informasi akuntansi yang efektif bergantung pada berhasil tidaknya kinerja antara sistem dan pemakai. Sistem informasi akuntansi menjadi bagian penting dalam upaya peningkatan efisiensi dan peningkatan kualitas informasi keuangan (Alsarayreh et al., 2011). Sistem informasi akuntansi yang efektif adalah sistem yang dapat menghasilkan informasi yang berkualitas. Sistem informasi yang efektif mampu meningkatkan kinerja indiviual atau pemakai (user) dalam mengerjakan kesesuaian tugasnya (DeLone dan McLean, 1992). Evaluasi pada pengguna atas kecocokan tugas dengan teknologi dapat dilakukan sebagai 
salah satu upaya peningkatan kinerja. Adanya kecocokan antara tugas yang dikerjakan dengan teknologi yang digunakan dapat meningkatkan kinerja menjadi lebih baik (Astuti dan Dharmadiaksa, 2014).

Sistem informasi yang baik akan membantu pengguna (user), faktor kenyamanan fisik terhadap sistem informasi perlu diperhatikan. Aditya dan Suardikha (2013) menyatakan bahwa kenyamanan fisik berpengaruh pada persepsi seorang pengguna dalam menyelesaikan tugas-tugas serta kewajibannya. Aditya dan Suardikha (2013) juga menyatakan bahwa faktor situasi berpengaruh pada persepsi seseorang dimana dimaksud dalam penelitian ini adalah keadaan sistem komputer yang digunakan oleh pengguna, adanya ketersediaan sistem komputer yang baik di sekitar pengguna komputer (user) dapat meningkatkan kinerja individualnya.Penelitian Rahmawati (2014) menyatakan, lingkungan kerja merupakan situasi serta kondisi psikologis dalam organisasi. Lingkungan kerja yang baik juga berpengaruh pada kinerja karyawan dalam melakukan tugasnya dengan optimal.

LPD merupakan wadah kekayaan ekonomi desa dan telah mengalami perkembangan yang cukup pesat serta telah memberikan kontribusi positif bagi pembangunan desa pakraman di Kota Denpasar. Omset yang dimiliki LPD juga cukup besar dilihat dari perkembangannya setiap tahun, yang mengindikasikan tingginya partisipasi masyarakat terhadap LPD, oleh sebab itu diperlukan penerapan sistem informasi akuntansi sebagai sarana dalam memudahkan pengelolaan data dan informasi. LPD di Kota Denpasar sebagian besar telah 
L. G. Sridarmaningrum dan Ni Luh Sari Widhiyani. Pengaruh ...

menerapkan sistem terkomputerisasi dalam pengolahan datanya, namun peneliti melihat masih banyak kinerja karyawan yang dinilai belum efektif.

Sistem yang ada tersebut belum dimanfaatkan secara maksimal oleh karyawan pemakai teknologi sistem informasi, dalam penerapannya tidak sedikit karyawan di LPD kurang percaya diri dalam megoperasikan SIA yang ada. Hal tersebut diakibatkan karena karyawan yang bekerja di LPD dipilih berdasarkan paruman melalui musyawarah mufakat tanpa mempertimbangkan latar belakang pendidikan serta lebih melihat sifat dan perilaku, sehingga rasa kekeluargaan dan solidaritas begitu besar dimiliki oleh karyawan LPD. Meskipun demikian, terdapat pula dampak burukya, dimana pengelolaan LPD biasanya menjadi kurang profesional dibandingkan dengan lembaga-lembaga keuangan lainnya.

Selain itu jumlah karyawan yang bekerja pada masing-masing LPD terbatas hal ini menyebabkan kurang efektifnya manfaat yang diberikan oleh teknologi sistem informasi tersebut khususnya dalam meningkatkan kinerja karyawan. Peneliti melihat fakta dimana kinerja karyawan LPD dalam menerapkan dan pemanfaatan teknologi sistem masih terdapat permasalahan yang muncul seperti lambatnya kinerja yang dihasilkan sehingga tidak efisien waktu dalam pembuatan laporan serta kurangnya informasi terkait maka, diperlukan sarana yang dapat meringankan tugas-tugas tersebut. Keberhasilan sistem informasi suatu lembaga keuangan khususnya LPD, tergantung bagaimana sistem dijalankan, kemudahan sistem yang dijalankan, kemudahan sistem itu bagi para pemakai serta dalam 
memanfaatkan tekologi tersebut yang nantinya akan berdampak pada kesesuaian tugasnya, kenyamanan fisik penggunanya dan lingkungan tempat kerja.

Pemanfaatan secara maksimal sistem yang terkomputerisasi secara menyeluruh dalam mengolah data akuntansidiharapkan membantu menyelesaikan persoalan-persoalan pada LPD. Teknologi sistem informasi yang diterapkan dengan baik diharapkan dapat memudahkan kinerja karyawan Lembaga Perkreditan Desa serta dapat menimbulkan kenyamanan fisik ataupun lingkungan kerja yang lebih baik terhadap karyawan, dengan demikian perlu diadakannya penelitian mengenai kinerja karyawan terhadap adanya penerapan sistem informasi akuntansi yang sudah berbasis komputer yang saat ini masih terdapat kekurangan dalam penggunaannya.

Penelitian ini menarik karena didorong dengan pentingnya pengetahuan tentang sistem informasi akuntansi bagi kinerja karyawan dalam mengerjakan tugas, serta dimotivasi oleh beberapa alasan salah satunya karena pemanfaatan teknologi informasi masih dinilai kurang efektif dalam membatu mengerjakan tugas karyawan. Penelitian ini menggunakan Technology Acceptance Model Theory (TAM) dan Technology to Perfomance Chain Theory (TPC). TAM merupakan salah satu model yang dibangun untuk menganalisis dan memahami faktor-faktor yang mempengaruhi diterimanya penggunaan teknologi komputer yang diperkenalkan pertama kali oleh Davis pada tahun 1986. Model TAM menyatakan para pengguna akan menggunakan sistem yang ada jika sistem 
L. G. Sridarmaningrum dan Ni Luh Sari Widhiyani. Pengaruh ...

tersebut dapat mempermudah dalam menyelesaikan pekerjaan serta memberikan manfaat bagi pengguna.

Technology-to-Performance Chain (TPC) adalah suatu model yang digunakan dalam memahami sikap pemakai sebagai prediktor dari pemakai dan kesesuaian tugas dengan teknologi sebagai prediktor kinerja individu (Jogiyanto, 2007:200). Individu yang dimaksud dalam model ini adalah pemakai (user) teknologi informasi, dimana teknologi tersebut dipergunakan untuk membantu pelaksanaan tugas-tugasnya. Karakteristik individu (pelatihan, pengalaman menggunakan komputer dan motivasi) dapat mempengaruhi bagaimana individu memanfaatkan teknologi sesuai dengan tugas-tugas yang mendukungnya.

Efektivitas adalah seberapa baik pekerjaan menghasilkan keluaran sesuai dengan yang diharapkan (Kristiana, 2012). Secara umum, efektivitas penggunaan atau pengimplementasian dapat dievaluasi dari kemudahan yang diperoleh oleh pengguna dalam melakukan pengelolaan data.TAM menjelaskan apabila sistem memberikan manfaat, maka sistem diakatakan efektif bagi penggunanya. Menurut Sajady dan Hashem (2008) efektivitas suatu sistem dilihat dari kontribusi sistem tersebut dalam menghasilkan informasi yang berkualitas, untuk evaluasi serta pengambilan keputusan maupun sebagai sarana pengendalian intern. Hasil penelitian oleh Awesejo (2013), Suratini (2015), menemukan pengaruh positif efektivitas penggunaan sistem informasi akuntansi terhadap kinerja. Hipotesis pertama yang diajukan yaitu.

$\mathrm{H}_{1}$ : $\quad$ Efektivitas penerapan sistem informasi akuntansi berpengaruh positif pada kinerja karyawan. 
Menurut Rahmawati (2014) menjelaskan bahwa, kesesuaian tugas berhubungan dengan sejauh mana kemampuan individual menggunakan teknologi informasi untuk meningkatkan kinerja individual dalam melaksanakan tugas. Menurut Jogiyanto (2008:240) dimensi kesesuaian pekerjaan (job fit) mengukur sejauh mana seseorang individual kepercayaan seseorang terhadap penggunaan teknologi bermanfaat bagi tugasnya. TPC adalah teori yang berhubungan dengan sikap pemakai dengan kesesuaian tugas teknologi. Konsep dimensi kesesuaian pekerjaan (job fit) mirip dengan kegunaan persepsian (perceived usefulness) yang dikenalkan oleh Davis (1989) di model penerimaan teknologi (technology acceptance model) mereka.

Penelitian Nurmalitasari (2010), Ashianti (2013), Syahroni (2014), serta Goodhue dan Thompson (1995) menemukan kecocokan tugas teknologi akan mengarah individual untuk mencapai kinerja yang lebih baik. Hasil penelitian dari Astuti dan Dharmadiaksa (2014) menyatakan bahwa kesesuaian tugas memiliki pengaruh positif. Berdasarkan penelitian sebelumnya, hipotesis yang diajukan yaitu.

$\mathrm{H}_{2}$ : Kesesuaian tugas dengan teknologi informasi berpengaruh positif pada kinerja karyawan.

Menurut Aditya dan Suardikha (2013) lingkungan sekitar user atau kenyamanan fisik juga dapat mendukung efektivitas sistem informasi perusahaan sedangkan menurut Maryati (2014:139) lingkungan kerja yang sehat dan baik akan berpengaruh terhadap kenyamanan kerja karyawan. Ketersediaan fasilitas dalam bidang sistem teknologi informasi membantu karyawan dalam 
L. G. Sridarmaningrum dan Ni Luh Sari Widhiyani. Pengaruh ...

menyelesaikan tugas dengan tepat waktu tanpa adanya hambatan. Hal ini berhubungan dengan teori TPC, apabila teknologi memberikan suatu kemudahan dalam mengerjakan tugas-tugas maka kenyamanan terhadap teknologi tersebut akan meningkat ini berhubungan dengan hasil kinerja karyawan.

Hasil penelitian oleh Aditya dan Suardikha (2013), serta Astuti dan Dharmadiaksa (2014) menyatakan kenyamanan fisik yang baik dapat meningkatkan kinerja karyawan. Larasdiputra dan Suryanawa (2014) dalam penelitiannya menyebutkan bahwa kenyamanan fisik berpengaruh terhadap kinerja karyawan. Penelitian Kurnia (2015) kenyamanan fisik berpengaruh terhadap kinerja karyawan. Selanjutnya, penelitian Romandhon dkk (2016) juga menyatakan bahwa hasil penelitian kenyamanan fisik berpengaruh terhadap kinerja karyawan. Berdasarkan penelitian sebelumnya maka dapat disimpulkan hipotesis sebagai berikut.

$\mathrm{H}_{3}$ : Kenyamanan fisik berpengaruh positif pada kinerja karyawan.

Lingkungan kerja merupakan salah satu faktor yang mendukung dalam terciptanya kepuasan kerja bagi karyawan meliputi kondisi tempat, hubungan kerja sama antar karyawan dan program pelayanan masyarakat. Hubungan lingkungan kerja yang baik, suasana kerja yang memungkinkan dan tersedianya fasilitas yang memadai serta dengan tingginya tingkat produktivitas kerja pada karyawan di dalam perusahaan tidak perlu diragukan lagi (Anoraga dan Widiyanti, 1993:130). Hasil penelitian dilakukan Hermawan (2003) menyatakan 
lingkungan kerja mempengaruhi efektivitas kinerja karyawan dalam melaksanakan tugasnya.

Rahmawati, dkk (2014), Untari dan Wahyuati (2014) menyatakan hasil penelitiannya bahwa lingkungan kerja berpengaruh nyata terhadap kinerja karyawan. Penelitian Kartini dan Budianto (2015) menyatakan bahwa lingkungan kerja berpengaruh terhadap kinerja karyawan. Utami (2017) bahwa lingkungan kerja berpengaruh terhadap kinerja karyawan Berdasarkan penelitian sebelumnya maka dapat disimpulkan hipotesis sebagai berikut.

$\mathrm{H}_{4}$ : Lingkungan kerja berpengaruh positif pada kinerja karyawan.

\section{METODE PENELITIAN}

Penelitian ini menggunakan pendekatan kuantitatif yang berbentuk asosiatif. Penelitian asosiatif adalah penelitian yang bertujuan untuk mengetahui pengaruh ataupun hubungan dua variabel atau lebih (Sugiyono, 2016:55), sementara itu pendekatan kuantitatif merupakan metode penelitian yang meneliti populasi atau sempel tertentu dengan tujuan untuk pengujian hipotesis (Sugiyono 2016:13). Desain penelitian ialah perencanaan terhadap penelitian yang akan dilakukan dan bertujuan untuk menyelenggarakan penelitian sehingga terdapat logika, baik dalam pengujian hipotesis maupun dalam menarik kesimpulan (Sugiyono, 2016:224). 


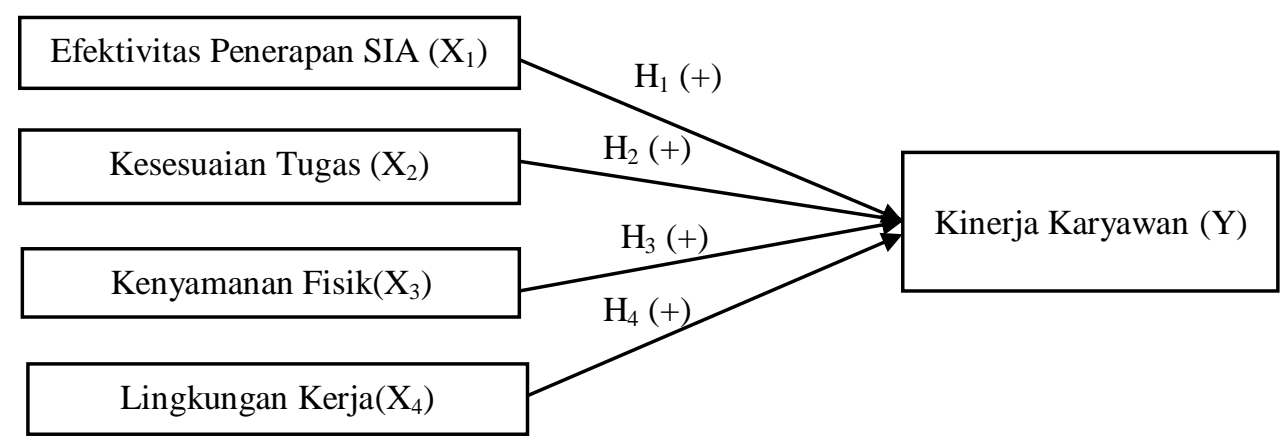

\section{Gambar 1. \\ Kerangka Konseptual}

Di kota Denpasar terdapat empat kecamatan yang masing-masing kecamatan terdapat LPD dimana LPD Kota Denpasar menurut data LPLPD merupakan yang pertama menerapkan sistem berbasis manual telah beralih ke sistem berbasis komputer sejak awal tahun 2000. Penelitian dilakukan di LPD yang terdapat di Kota Denpasar. Indikator pengukuran variabel efektivitas penerapan SIA yang digunakan dalam penelitian ini diadopsi dari penelitian Astuti dan Dharmadiaksa (2014) yaitu keamanan data, waktu, ketelitian, relevansi dan variasi laporan.

Indikator pengukuran variabel kesesuaian tugas dengan teknologi informasi yang digunakan dalam penelitian ini diadopsi dari penelitian Astusi dan Dharmadiaksa (2014) yaitu keakuratan, aksesibilitas, asistensi, tingkat rincian yang tepat dan kemudahan menggunakan perangkat keras dan lunak. Dalam penelitian ini pengukuran kenyamanan fisik terdiri dari 4 indikator yang diadopsi dari penelitian Aditya dan Suardikha (2013) yaitu kelengkapan peralatan komputer, kelengkapan aplikasi pada komputer, kondisi perangkat komputer yang digunakan oleh pengguna baik atau tidak dan keamanan data. Dalam penelitan ini 
pengukuran lingkungan kerja diadopsi dari penelitian Kartini dan Budianto (2015) terdiri dari 3 indikator yaitu suasana kerja, hubungan dengan rekan kerja dan tersedianya fasilitas kerja.

Variabel dependen pada penelitian ini yaitu kinerja karyawan. Indikator pegukuran variabel karyawan yang digunakan dalam penelitian ini diadopsi dari penelitian Astuti dan Dharmadiaksa (2014) yaitu produktivitas, efektivitas, kuantitas kerja, kualitas kerja dan pelayanan sistem komputer. Variabel-variabel independen dan variabel dependen dalam penelitian ini diukur menggunakan skala likert. Penelitian ini menggunakan data kuantitatif yaitu jumlah karyawan pada LPD di Kota Denpasar dan data skor jawaban kuesioner responden. Data kualitatif yang digunakan adalah daftar LPD di Kota Denpasar. Sumber data penelitian ini yaitu data primer dan data sekunder. Data primer yaitu jawaban responden darikuesioner yang telah diberikan. Data sekunder yaitu daftar LPD di Kota Denpasar.

Berdasarkan data yang diperoleh dari Lembaga Pemerdayanaan Lembaga Perkreditan Desa (LPLPD) tahun 2007-2016 terdapat 35 LPD di Kota Denpasar dan memiliki karyawan berjumlah 480 orang. Populasi pada penelitian ini adalah karyawan yang menggunakan sistem terkomputerisasi yang berjumlah 212 orang. Kriteria pemilihan sampel dalam penelitian ini adalah karyawan yang bekerja lebih dari 1 tahun, terlibat secara langsung dengan sistem informasi dan karyawan yang menduduki jabatan dalam LPD di Kota Denpasar. Pada penelitian yang dijadikan responden di setiap LPD sebanyak 3 orang karena paling terlibat dalam 
L. G. Sridarmaningrum dan Ni Luh Sari Widhiyani. Pengaruh ...

penggunaan sistem informasi akuntansi, yaitu meliputi Kepala LPD, Bendahara dan Tata usaha. Oleh karena itu, maka didapatkan sampel yang memenuhi kriteria berjumlah 105 orang responden. Metode pengumpulan data yang digunakan dalam penelitian ini adalah dengan kuesioner, wawancara, dan observasi yang dilakukan langsung ke Lembaga Perkreditan Desa di Kota Denpasar.

Teknik analisis data yang digunakan dalam penelitian ini adalah regresi linear berganda. Model regresi berganda dalam penelitian ini adalah sebagai berikut:

$\mathrm{Y}=\alpha+\beta_{1} \mathrm{X}_{1}+\beta_{2} \mathrm{X}_{2}+\beta_{3} \mathrm{X}_{3}+\beta_{4} \mathrm{X}_{4}+\mathrm{e}$

Keterangan:

$\mathrm{Y}=$ Kinerja Karyawan

$\alpha=$ Konstanta

$\mathrm{X}_{1}=$ Efektivitas penerapan sistem informasi akuntansi

$\mathrm{X}_{2}=$ Kesesuaian tugas

$\mathrm{X}_{3}=$ Kenyamanan fisik

$\mathrm{X}_{4}=$ Lingkungan kerja

$\beta_{1}=$ Koefisien regresi efektivitas penerapan sistem informasi akuntansi

$\beta_{2}=$ Koefisien regresi kesesuaian tugas

$\beta_{3}=$ Koefisien regresi kenyamanan fisik

$\beta_{4}=$ Koefisien regresi lingkungan kerja

e $\quad$ Komponen error

\section{HASIL DAN PEMBAHASAN}

Uji validitas dilakukan oleh peneliti untuk menguji sejauh mana ketepatan dan kecermatan alat ukur dalam melakukan fungsi ukurnya. Hasil uji validitas pada Tabel 1. penelitian ini menunjukkan bahwa seluruh item pernyataan mempunyai nilai korelasi lebih besar dari 0,30 maka, seluruh butir pernyataan dinyatakan valid. Pada variabel $X_{1}$ menunjukkan nilai korelasi sebesar 0,667 sampai dengan 0,779. Pada variabel $\mathrm{X}_{2}$ menunjukkan nilai korelasi sebesar 0,679 sampai dengan 
0,801. Pada variabel $\mathrm{X}_{3}$ menunjukkan nilai korelasi sebesar 0,332 sampai dengan 0,904. Pada variabel $\mathrm{X}_{4}$ menunjukkan nilai korelasi sebesar 0,772 sampai dengan 0,845 dan pada variabel Y menujukkan nilai korelasi sebesar 0,549 sampai dengan 0,781. Sehingga seluruh item pernyataan tersebut layak digunakan sebagai instrumen untuk mengukur data penelitian.

Tabel 1.

Hasil Uji Validitas

\begin{tabular}{lccc}
\hline \multicolumn{1}{c}{ Variabel } & Item Pernyataan & NilaiKorelasi & Keterangan \\
\hline Efektivitas penerapan & $\mathrm{X}_{1.1}$ & 0,768 & Valid \\
sistem informasi & $\mathrm{X}_{1.2}$ & 0,754 & Valid \\
akuntansi $\left(\mathrm{X}_{1}\right)$ & $\mathrm{X}_{1.3}$ & 0,779 & Valid \\
& $\mathrm{X}_{1.4}$ & 0,667 & Valid \\
Kesesuaian tugas & $\mathrm{X}_{1.5}$ & 0,702 & Valid \\
dengan teknologi & $\mathrm{X}_{2.1}$ & 0,776 & Valid \\
informasi $\left(\mathrm{X}_{2}\right)$ & $\mathrm{X}_{2.2}$ & 0,788 & Valid \\
& $\mathrm{X}_{2.3}$ & 0,756 & Valid \\
& $\mathrm{X}_{2.4}$ & 0,801 & Valid \\
Kenyamanan fisik & $\mathrm{X}_{2.5}$ & 0,679 & Valid \\
$\left(\mathrm{X}_{3}\right)$ & $\mathrm{X}_{3.1}$ & 0,890 & Valid \\
& $\mathrm{X}_{3.2}$ & 0,904 & Valid \\
Lingkungan kerja $\left(\mathrm{X}_{4}\right)$ & $\mathrm{X}_{3.3}$ & 0,332 & Valid \\
& $\mathrm{X}_{3.4}$ & 0,806 & Valid \\
& $\mathrm{X}_{4.1}$ & 0,772 & Valid \\
Kinerja Karyawan & $\mathrm{X}_{4.2}$ & 0,845 & Valid \\
$(\mathrm{Y})$ & $\mathrm{X}_{4.3}$ & 0,786 & Valid \\
& $\mathrm{Y}_{1}$ & 0,549 & Valid \\
& $\mathrm{Y}_{2}$ & 0,661 & Valid \\
& $\mathrm{Y}_{3}$ & 0,781 & Valid \\
& $\mathrm{Y}_{4}$ & 0,765 & Valid \\
& $\mathrm{Y}_{5}$ & 0,713 & Valid \\
\hline
\end{tabular}

Sumber: Data diolah, 2017

Uji reabilitas dilakukan untuk mengetahui sejauh mana hasil pengukuran tetap konsisten, jika dilakukan dua kali atau lebih terhadap yang sama dengan menggunakan alat ukur yang sama. Instrumen dikatakan reliabel jika instrumen tersebut memiliki nilai cronbach's alphalebih dari 0,60. Hasil uji reliabilitas pada Tabel 2. memperlihatkan nilai cronbach's alpha pada semua butir pertanyaan 
dalam variabel adalah reliabel atau handal, sehingga butir-butir pertanyaan dalam variabel penelitian dapat digunakan untuk penelitian selanjutnya.

Tabel 2.

Hasil Uji Reliabilitas

\begin{tabular}{lcc}
\hline \multicolumn{1}{c}{ Variabel } & Nilai Cronbach's Alpha & Keterangan \\
\hline Efektivitas penerapan SIA $\left(\mathrm{X}_{1}\right)$ & 0,784 & Reliabel \\
Kesesuaian Tugas $\left(\mathrm{X}_{2}\right)$ & 0,818 & Reliabel \\
Kenyamanan Fisik $\left(\mathrm{X}_{3}\right)$ & 0,753 & Reliabel \\
Lingkungan Kerja $\left(\mathrm{X}_{4}\right)$ & 0,716 & Reliabel \\
Kinerja Karyawan $(\mathrm{Y})$ & 0,734 & Reliabel \\
\hline
\end{tabular}

Sumber: Data diolah, 2017

Uji normalitas bertujuan untuk mengetahui apakah di dalam sebuah model regresi, variabel terikat, variabel bebas atau keduanya mempunyai distribusi normal atau tidak. Apabila Asymp. Sig lebih besar dari level of significant yang dipakai $(0,05)$, maka data dikatakan berdistribusi normal. Berdasarkan hasil uji normalitas penelitian ini menunjukkan signifikansi yang diperoleh nilainya lebih besar dari taraf siginifikansi 0,05 sehingga dinyatakan model berdistribusi normal.

Uji multikolinearitas digunakan untuk menguji apakah dalam model regresi ditemukan adanya korelasi antar variabel bebas. Jika nilai toleransi lebih dari 0,1 (10\%) atau VIF kurang dari 10 maka dikatakan tidak ada multikolinearitas. Hasil uji multikolinearitas yang diperoleh pada penelitian ini menyatakan dalam model regresi penelitian ini tidak terjadi gejala multikolinearitas. Hal ini dibuktikan dengan nilai tolerance lebih dari $10 \%$ atau VIF kurang dari 10.

Uji heteroskedastisitas bertujuan untuk menguji apakah model regresi terjadi ketidaksamaan varians dari variabel absolute residual pengamatan ke pengamatan yang lain. Jika tingkat signifikansi berada di atas 0,05 maka model 
regresi ini bebas dari masalah heteroskedastisitas. Berdasarkan hasil uji heteroskedastisitas pada penelitian ini diperoleh tingkat signifikansi variabel bebas di atas 0,05 sehingga dinyatakan model regresi bebas dari heteroskedastisitas. Berdasarkan hasil uji normalitas, uji multikolinearitas dan uji heteroskedastisitas yang diperoleh pada penelitian ini maka dapat dinyatakan bahwa model regresi yang digunakan telah lolos uji asumsi klasik.

Uji regresi linier berganda bertujuan untuk mengetahui pengaruh masingmasing variabel, maka digunakan analisis statistik regresi linier berganda, t-test dan F-test. Tabel 3. menunjukkan $\mathrm{R}$ square sebesar 0,756 yang berarti pengaruh variabel-variabel independen terhadap variabel dependen dalam penelitian ini sebesar $75,6 \%$. Sisanya sebesar $24,4 \%$ dipengaruhi variabel lain diluar model penelitian. Berdasarkan Tabel 3. nilai sig. $F=0,000$ lebih kecil dari taraf signifikansi 0,05. Hal tersebut berarti persepsi karyawan tentang efektivitas penerapan sistem informasi akuntansi, kesesuaian tugas dengan teknologi informasi, kenyamanan fisik dan lingkungan kerja berpengaruh terhadap kinerja karyawan LPD di Kota Denpasar.

Tabel 3.

Hasil Uji Regresi Linier Berganda

\begin{tabular}{lccc}
\hline \multicolumn{1}{c}{ Nama Variabel } & Koefisien Regresi & t-test & Sig. t \\
\hline $\begin{array}{l}\text { Efektivitas penerapan sistem } \\
\text { informasi akuntansi }\end{array}$ & 0,216 & 3,100 & 0,003 \\
Kesesuaian tugas dengan & & & \\
teknologi informasi & 0,412 & 5,789 & 0,000 \\
Kenyamanan fisik & & & \\
Lingkungan kerja & 0,091 & 2,259 & 0,026 \\
Konstanta & 0,440 & 4,009 & 0,000 \\
R & & 1,046 & \\
R square & & 0,869 & \\
F hitung & & 0,756 & \\
F sig & & 77,327 & \\
Sumber: Data diolah, 2017 & 0,000 &
\end{tabular}


Tabel 4.

Hasil Uji Hipotesis (Uji t)

\begin{tabular}{|c|c|c|c|c|c|c|c|}
\hline \multirow[b]{2}{*}{ Model } & \multicolumn{2}{|c|}{$\begin{array}{l}\text { Unstandardized } \\
\text { Coefficients }\end{array}$} & \multirow{2}{*}{$\begin{array}{c}\text { Standardized } \\
\text { Coefficients } \\
\text { Beta } \\
\end{array}$} & \multirow[b]{2}{*}{$\mathbf{T}$} & \multirow[b]{2}{*}{ Sig. } & \multirow[b]{2}{*}{ Tolerance } & \multirow[b]{2}{*}{ VIF } \\
\hline & B & Std. Error & & & & & \\
\hline (Constant) & 1,046 & 0,967 & & 1,083 & 0,282 & & \\
\hline EfekPenerapn & 0,216 & 0,070 & 0,236 & 3,100 & 0,003 & 0,432 & 2,367 \\
\hline KesesTugas & 0,412 & 0,071 & 0,452 & 5,789 & 0,000 & 0,401 & 2,493 \\
\hline KenyamFisik & 0,091 & 0,040 & 0,113 & 2,259 & 0,026 & 0,971 & 1,030 \\
\hline LingKerja & 0,440 & 0,110 & 0,276 & 4,009 & 0,000 & 0,514 & 1,947 \\
\hline
\end{tabular}

Sumber: Data diolah, 2017

Uji hipotesis (Uji t) digunakan untuk mengetahui pengaruh masing-masing variabel bebas $(\mathrm{X})$, terhadap variabel terikat kinerja karyawan. Apabila sig $<0,05$ dan $\beta \mathrm{i}>0$ maka variabel bebas berpengaruh terhadap variabel terikat $(\mathrm{Y})$. Berdasarkan Tabel 4. menunjukkan nilai t hitung variabel efektivitas penerapan sistem informasi akuntansi sebesar 3,100 dengan nilai sig $0,003<\alpha(0,05)$. Hal ini menunjukkan adanya pengaruh positif efektivitas penerapan sistem informasi akuntansi pada variabel kinerja. Hal ini berarti efektivitas penerapan sistem informasi akuntansi yang semakin baik dapat meningkatkan kinerja karyawan LPD tersebut. Suatu sistem sistem informasi diterapkan dengan baik maka akan memberikan manfaat bagi karyawan LPD dalam meningkatkan kinerjanya, seperti software yang digunakan dalam mengolah data. Penggunaan sistem informasi akuntansi harus didukung dengan kemampuan personal pemakai sistem tersebut, sehingga SIA dapat berjalan secara efektif dan mampu meningkatkan kinerja LPD dan kinerja karyawannya.

Hasil penelitian ini sejalan dengan penelitian yang dilakukan Awesejo (2013), Suratini (2015), Antasari (2015) dan Arsiningsih (2015) menemukan bahwa efektivitas penggunaan berpengaruh positif pada kinerja individual 
pengguna SIA. Hasil tersebut menunjukkan bahwa efektivitas penerapan sistem informasi akuntansi pada LPD dapat meningkatkan efisiensi serta mendukung terjadinya proses kerja yang lebih efektif terhadap karyawan.

Berdasarkan Tabel 4. menunjukkan nilai t hitung variabel kesesuaian tugassebesar 5,789 dengan signifikansi $0,000<\alpha(0,05)$ maka $\mathrm{H}_{0}$ ditolak. Hal tersebut menunjukkan adanya pengaruh positif antara variabel kesesuaian tugas dengan teknologi informasi dengan variabel kinerja. Kesesuaian tugas terkait kemampuan karyawan LPD memanfaatkan teknologi infomasi dalam mengerjakan tugas-tugasnya. Hasil ini sejalan dengan hasil penelitian yang dilakukan oleh Nurmalitasari (2010), Ashianti (2013) serta Astuti dan Dharmadiaksa (2014). Hasil tersebut juga sejalan dengan penelitian Syahroni (2014). Hal ini berarti adanya kesesuaian tugas dengan kemampuan individu dan teknologi yang digunakan, akan menyebabkan peningkatan pada kinerja karyawan.

Berdasarkan Tabel 4. menunjukkan nilai t hitung variabel kenyamanan fisiksebesar 2,259 dengan nilai sig $0,026<\alpha \quad(0,05)$. Hasil penelitian ini mengindikasikan adanya pengaruh positif kenyamanan fisik terhadap kinerja karyawan. Kinerja karyawan yang didukung oleh kelengkapan peralatan komputer, kelengkapan aplikasi pada komputer, kondisi perangkat komputer dan keamanan data dapat meningkatkan kinerja karyawan LPD tersebut sehingga adanya rasa nyaman dalam bekerja dan dapat dipastikan bahwa produktivitas akan meningkat. 
L. G. Sridarmaningrum dan Ni Luh Sari Widhiyani. Pengaruh ...

Hasil penelitian ini mendukung hasil penelitian yang dilakukan oleh Aditya dan Suardikha (2013) menyatakan kenyamanan fisik yang baik dapat meningkatkan kinerja karyawan. Hasil penelitian Astuti dan Dharmadiaksa (2014) menyatakan kenyamanan fisikakan mempengaruhi para pemakai sistem informasi serta para pemakai sistem informasi dapat lebih fokus dalam menyelesaikan tugas-tugasnya. Penelitian Larasdiputra dan Suryanawa (2014) serta penelitan Kurnia (2015) menyatakan kenyamanan fisik berpengaruh terhadap kinerja karyawan. Selanjutnya, penelitian Romandhon dkk (2016) juga menyatakan bahwa hasil penelitian kenyamanan fisik berpengaruh terhadap kinerja karyawan.

Berdasarkan Tabel 4. menunjukkan nilai t hitung variabel lingkungan kerja sebesar 4,009 dengan nilai sig $0,000<\alpha(0,05)$. Hasil penelitian mengindikasikan adanya pengaruh positif lingkungan kerja dengan kinerja karyawan. Hubungan di lingkungan kerja yang baik, suasana kerja yang memungkinkan dan tersedianya fasilitas yang memadai serta dengan tingginya tingkat produktivitas kerja pada LPD maka akan meningkatkan kinerja karyawan, sehingga mampu untuk mengerjakan tugasnya dengan lebih baik. Oleh karena itu, lingkungan kerja merupakan salah satu faktor yang mendukung dalam terciptanya kepuasan kerja bagi karyawan meliputi kondisi tempat, hubungan kerja sama antar karyawan dan program pelayanan masyarakat pada LPD.

Hasil penelitian ini sejalan dengan penelitian yang dilakukan oleh Hermawan (2003) menyatakan lingkungan kerja mempengaruhi efektivitas kinerja karyawan dalam melaksanakan tugasnya. Rahmawati, dkk (2014) menyatakan 
lingkungan kerja fisik dan lingkungan kerja non fisik juga berpengaruh positif terhadap motivasi dan efektivitas kerja. Untari dan Wahyuati (2014) menyatakan hasil penelitiannya bahwa lingkungan kerja berpengaruh nyata terhadap kinerja karyawan. Penelitian Kartini dan Budianto (2015) menyatakan bahwa lingkungan kerja berpengaruh terhadap kinerja karyawan, begitu juga dengan penelitian yang dilakukan oleh Utami (2017) bahwa lingkungan kerja berpengaruh terhadap kinerja karyawan.

\section{SIMPULAN}

Simpulan penelitian ini yaitu efektivitas penerapan sistem informasi akuntansi, kesesuaian tugas, kenyamanan fisik,dan lingkungan kerja berpengaruh positif pada kinerja karyawan. Hasil tersebut menunjukkan bahwa efektivitas penerapan sistem informasi akuntansi, kesesuaian tugas, kenyamanan fisik, dan lingkungan kerja yang semakin baik pada LPD di Kota Denpasar akan meningkatkan kinerja karyawan dalam mengerjakan tugasnya.

Berdasarkan simpulan tersebut maka peneliti dapat memberikan beberapa saran yaitu diharapkan dapat menjaga keamanan sistem informasi agar tidak mudah mengalami gangguan-gangguan baik dari faktor internal maupun eksternal. Diharapkan dapat memjaga serta mampu untuk meningkatkan kenyamanan fisik bagi para karyawan agar tetap dapat mengerjakan tugasnya dengan lebih baik tanpa adanya gangguan dari sistem itu sendiri. Diharapkan dapat menjaga lingkungan kerja yang harmonis di lingkungan kerja agar terciptanya kerukunan 
antar karyawan yang nantinya akan berdampak pada peningkatan kinerja karyawan.

\section{REFERENSI}

Aditya, Puja Pratama dan Suardhika, I Md. Sadha. 2013. Keahlian Pemakai Komputer dan Kenyamanan Fisik Memoderasi Pengaruh Efektivitas Sistem Informasi Akuntansi Terhadap Kinerja Karyawan di PT. Bank Sinar Harapan Bali Denpasar. E-Jurnal Akuntansi Universitas Udayana, 5(2), pp: 361-381

Alsarayreh M.N., Jawabreh O.A., Jaradat M.F., and Alamro S.A. 2011. Technoloical Impact on Effectiveness of Accounting Information System (AIS) Applied by Aqaba Tourist Hotels. European Journal of Scientific Research, 59(3), pp: 361-169.

Al-eqab, Mahmod and Dalia Adel. 2013. The Impact of IT Sophosticutions on the Perceived Useful of Accounting Information Characteristics among Jordanian Listed Companies. International Jurnal of Business and Social Science. 4(3), pp: 143-155

Anoraga, dan Widiyanti. 1993. Psikologi dalam Perusahaan. Jakarta: Rineka

Astuti, Ni made Marlita Puji dan Ida Bagus Dharmadiaksa. 2014. Pengaruh Efektivitas Sistem Informasi Akuntansi, Pemanfaatan dan KesesuaianTugas pada Kinerja Karyawan. ISSN: 2302-8556 E-Jurnal AkuntansiUniversitas Udayana. 9.2 (2014): 373-384

Ashianti, Agnes. 2013. Pengaruh Kesesuaian Tugas-Teknologi, Kepercayaan dan Efektivitas Sistem Informasi Akuntansi Terhadap Kinerja Individu Pada Pasar Swalayan di Kota Tanggerang. Ultima Accounting Universitas Multimedia Nusantara Vol.5.No.2

Awesejo, O.J., Kekwaletswe, R, M., Pretorius, P and Zuva, T . 2013. The Effect of Accounting Information System in Accounting. 3(1), pp:142-150

Bodnar, George H dan Hoopwood, William S. 2006. Sistem Informasi Akuntansi. Edisi Kesembilan. Yogyakarta: ANDI.

Davis, F.D. 1989. Perceived Usefulness, Perceived Ease of Use, and Acceptance of Information System Technology. Management Information Systems Quartely, 13(3), pp:319-339

DeLone, W., dan McLean, E.R. Information System Succes : The Qusets for Dependent Variable, Information System Research, (3:1). 1992. Pp. 60-95. 
Edison, G., Manuere, F , Joseph, M., and Gutu, K. 2012. Evaluation of Factors Influencing Adoption of Accounting Information by Small to Medium Enterprises in Chinhovi. Journal of Contemporary Research in Business, 4(6), pp: 1126-1141.

George, N. O., Elijah Marongan, \& Peter Kibet. 2012. Factors Influencing Employee Performance Appraisal System. International Journal of Business Social Science, 3(20), pp:37-46.

Goodhue, D.L., and Thompson, R.L. 1995. Task Technology Fit and Individual Performance, MIS Quarterly, pp: 213-236.

Hermawan, Didik. 2003. Pengaruh Lingkungan Kerja Terhadap Semangat Kerja Karyawan Pada Perum Pegadaian Cabang Tulungagung. Skripsi S-1 Fakultas Ekonomi Universitas Jember

Jogiyanto, HM. 2007. Sistem Informasi Keperilakuan. Yogyakarta: ANDI

Jogiyanto. 2008. Model Kesuksesan Sistem Teknologi Informasi. Yogyakarta: Andi.

Kartini, Amelia dan Budianto, Tri Aji.A. 2015. Pengaruh Lingkungan Kerja Terhadap Kinerja Pegawai pada PT. Perusahaan Gas Negara (PERSERO) Tbk SBU Distribusi Wilayah I Jakarta. Jurnal Ilmiah Prodi Manajemen Universitas Pemulang.

Kelton, A. S., Robin R. P, dan Brand M. T. 2010. An Effects of Information Presentaton Format on Judgement and Decision Making: A Review of The Information System Research. Journal of Information System, 24(2), pp:79105.

Kristiana, Wahyu. 2012. Analisis Pengaruh Efektivitas Teknologi Sistem Informasi Akuntansi Terhadap Kinerja Individual. Jurnal Akuntansi Fakultas Ekonomi Universitas Gunadarma

Kurnia, Irma Yuni. 2015. Pengaruh Keahlian Pemakai Komputer, Kenyamanan Fisik, Kesesuaian Tugas dan Pemanfaatan Teknologi Informasi terhadap Kinerja Karyawan (Survei pada PT. Pupuk Kujang Cikampek). Skripsi (S1), Fakultas Ekonomi Unpas.

Larasdiputra GD, dan Suryanawa IK. 2014. Penerapan Sistem Informasi Akuntansi Pada Bank Perkreditan Rakyat Sari Jaya Sedana Klungkung. EJurnal Akuntansi Universitas Udayana 7.3 ISSN: 2302-8556791-805

Maryati. 2014. Manajemen Perkantoran Efektif. Yogyakarta: UPP STIM YKPN. 
Marija, Tokic, Mateo Spanja, Iva Tokic, Ivona Blazevic. 2011. Functional Structure of Entrepreneurial Accounting Information System. International Journal Of Engineering 9(2).

Nurmalitasari, Marina Dyah. 2010. Pengaruh Kesesuaian Tugas Teknologi, Keahlian Pengguna, dan Manfaat Teknologi Terhadap Kinerja Karyawan (Survei pada Karyawan Bank Bagian Akuntansi di Purwodadi). Skripsi Universitas Muhammadiyah Surakarta.

Nwokeji, Emeka N. A. 2012. Repositioning Accounting Information System Through Effective Data Quality Management: A Framework For Reducing Cost And Improving Performance. International Journal Of Scientific \& Technology Research Volume 1, Issue 10, November 2012.

Ogah, Idagu Joseph. 2013. An evaluation of the Relevance of Accounting System as Management Decision Tool in Union Bank of Nigeria Plc, Uyo Branch of Akwa Ibom. Greener Journal of Business and Management Business Study, 3(1), pp: 38-44

Rahmawati, Nela Pima. Swasto, Bambang. Prasetya, Arik. 2014. Pengaruh Lingkungan Kerja Terhadap Kinerja Karyawan Pada Kantor Pelayanan Pajak Pratama Malang Utara. Jurnal Fakultas Ilmu Administrasi Universitas Brawijaya

Rai, A., Lang, S.S. and Welker, R.B. 2002. Assessing Validity of IS Succes Models: An Empirical Test and Theoritical Analysis. Information Sistem Research. 13(1), pp: 29-34.

Romandhon, dkk. 2016. Pengaruh Efektivitas Penggunaan Sistem Informasi Akuntansi, Kepercayaan Terhadap Sistem Informasi Akuntansi, Kemampuan Teknik Pemakai Sistem Informasi Akuntansi dan Kenyamanan Fisik Terhadap Kinerja Individu. Jurnal Fakultas Ekonomi Universitas Sains Al-Qur'an.

Sajady, H., Dastgir and H. Hashem Nejad. 2008. Evaluation The Effectiveness of Accounting Information System. International Journal of Information Science and Technology. 6(2).pp: 49-59.

Sugiyono. 2016. Metode Penelitian Kuantitatif, Kualitatif dan R\&D. Cetakan ke 23 Bandung: CV. Alfabeta.

Suratini, Ni Putu Eka. 2015. Pengaruh Efektivitas Sistem Informasi Akuntansi dan Penggunaan Teknologi Informasi Terhadap Kinerja Individual pada PT. Bank Pembangunan Daerah Bali Kantor Cabang Singaraja. E-Journal Akuntansi Universitas Pendidikan Ganesha S1. 3(1) 
Syahroni, Khoirul Habib. 2014. Pengaruh Pemanfaatan Teknologi Informasi, Kesesuaian Tugas-Teknologi Informasi, dan Kepercayaan atas Teknologi Informasi Terhadap Kinerja Individual (Studi Kasus pada Bank BPR di Kabupaten Karanganyar). Skripsi Fakultas Ekonomi dan Bisnis Universitas Muhammadyah Surakarta.

Untari, Siti dan Wahyuati, Aniek. 2014. Pengaruh Kompetensi dan Lingkungan Kerja Terhadap Kinerja Karyawan. Jurnal Ilmu dan Riset Manajemen (STIESIA) Surabaya.

Urquia, Elena. 2011. An Effect of Accounting Information System on Performance Measure: Empirical Evidence in Spanish. Journal International of Digital Accounting Research, 11(2), pp:25-43.

Utami, dkk. 2017. Pengaruh Lingkungan Kerja Terhadap Kinerja Karyawan Melalui Variabel Mediator Motivasi Kerja. Jurnal Fakultas Ilmu Admiistrasi Universitas Brawijaya. 